\title{
Vitis vinifera Assisted Silver Nanoparticles with Antibacterial and Antiproliferative Activity against Ehrlich Ascites Carcinoma Cells
}

\author{
A. K. M. Asaduzzaman, ${ }^{1}$ Byung-Soo Chun, ${ }^{2}$ and Syed Rashel Kabir ${ }^{1}$ \\ ${ }^{1}$ Department of Biochemistry and Molecular Biology, Rajshahi University, Rajshahi 6205, Bangladesh \\ ${ }^{2}$ Department of Food Science and Technology, Pukyong National University, 45 Yongso-Ro, Nam-Gu, Busan 608-737, Republic of Korea
}

Correspondence should be addressed to A. K. M. Asaduzzaman; jonyasad2005@ru.ac.bd

Received 24 May 2016; Accepted 27 July 2016

Academic Editor: Xiangwu Zhang

Copyright (C) 2016 A. K. M. Asaduzzaman et al. This is an open access article distributed under the Creative Commons Attribution License, which permits unrestricted use, distribution, and reproduction in any medium, provided the original work is properly cited.

Vitis vinifera extract assisted silver nanoparticles (AgNPs) were biosynthesized that was confirmed primarily by color change and a sharp plasmon absorption band was found at $449 \mathrm{~nm}$. Biosynthesized AgNPs shape was spherical and the particle size of $17 \mathrm{~nm}$ in average was confirmed by transmission electron microscopy (TEM) images. Functional groups of AgNPs were identified by Fourier transform infrared spectroscopy (FTIR). Streptococcus aureus was the most sensitive bacteria towards the assisted V. vinifera AgNPs as their growth was $90 \%$ inhibited at $100 \mu \mathrm{g} / \mathrm{mL}$ concentration. That was also confirmed by the zone of inhibition study. Up to $96 \mathrm{~h}$, no biofilm was observed for K. pneumoniae at $40 \mu \mathrm{g} / \mathrm{mL}$ of AgNPs. Although AgNPs showed a mild toxicity against brine shrimp nauplii, it showed a remarkable level of antiproliferative activity against Ehrlich ascites carcinoma (EAC) cells.

\section{Introduction}

Nanobiotechnology is an emerging field of biomedical and pharmaceutical areas due to the boosting properties of materials in the form of nanosized particles. Many noble metals like palladium, silver, platinum, and gold are found naturally. They put on display a particularly wide range of material behaviors along the atomic to bulk transition [1]. Among these noble metals, silver has wide applications in jewelry, dental alloy, and health additive in traditional Bangladeshi, Chinese, and Indian Ayurvedic medicine [2]. Due to the unique physical and chemical properties of silver nanoparticles, they received substantial attentions which differ to a great extent from those of bulk materials, as well as their potential for technological applications [3]. Silver nanoparticles have widely used application in drug delivery, sensor application, cosmetics, wound healing, and textile industry and also have medical application as antibacterial, antifungal, and anticancer agents [4-6].

Conventional physical and chemical methods, for example, laser radiation, gamma rays, combination of different toxic hazardous capping, and stabilizing agents, are being widely used for the synthesis of AgNPs [7]. These toxic chemicals can become hazardous for medical application. Nowadays, a clean, nontoxic, and environmental friendly synthetic approach is getting introduced for the synthesis of AgNPs. Green biosynthesis of AgNPs is an efficient nontoxic, cost effective, and environment-friendly method that can be used instead of physical and chemical methods. It can be easily produced in a large scale and there is no need to use high pressure, energy, temperature, and toxic chemicals in this method.

V. vinifera (grape) has more medicinal and nutritional values and it has been heralded for thousands of years. There are many phenolic compounds present in all parts of grapes which are believed to contain antioxidants and exhibit antimicrobial activities [8]. Varieties of grapes with different colors, such as green, black, and red-black, are found in Bangladesh. Many researchers have produced silver and gold nanoparticles with diverse physical properties from juice, seed, and leaf extracts of black grapes and have shown only antibacterial activity of that nanoparticle $[9,10]$. As far as 
we know, production of nanoparticles from green grapes and determination of their cytotoxic and anticancer activity are not yet reported. Therefore, the present study was targeted to produce silver nanoparticles from green grapes and observed their antibacterial and antiproliferative activity with toxicity studies.

\section{Materials and Methods}

2.1. Chemicals and Reagents. Silver nitrate, Hoechst 33342, fetal bovine serum, and RPMI-1640 were purchased from Sigma, USA. All other chemicals or reagents throughout the experiment used were of highest analytical grades.

2.2. Sample Preparation. Grapes (V. vinifera) were collected from the local market of Rajshahi, Bangladesh. They were washed with deionized water and dried by water absorbent paper. Then, it was cut into small pieces by a sterilized knife and homogenized with deionized water at $2: 1 \mathrm{ratio}(\mathrm{w} / \mathrm{v})$. The homogenized sample was filtered by Whatman filter paper and then centrifuged at 10,000 g. Finally, a clear supernatant solution ( $\mathrm{pH} 4.1)$ was collected and stored at $4^{\circ} \mathrm{C}$ until further use.

2.3. Silver Nanoparticles Synthesis. During the synthesis of silver nanoparticles, grape extract $(\mathrm{pH} 4.1)$ was mixed with freshly prepared $2.5,3.0,3.5,4.0$, and $4.5 \mathrm{mM}$ of silver nitrate solution at $1: 1$ ratio $(\mathrm{v} / \mathrm{v})$ and kept at room temperature for $4 \mathrm{~h}$. When color of the solution slowly turned from white to brown, it indicated the formation of silver nanoparticles and then was subjected to UV-visible spectra analysis.

2.4. UV-Visible Spectra Analysis. Reduction of silver ions in silver nanoparticles was monitored by UV-visible spectroscopy (Shimadzu, Japan) at the wavelength range of 250$700 \mathrm{~nm}$. $0.2 \mathrm{~mL}$ of silver nanoparticles aliquots was diluted with $2 \mathrm{~mL}$ of distilled water and then the absorbance was recorded. Sample showing the highest peak was centrifuged at $10,000 \mathrm{~g}$. The pellet was dissolved in deionized water and washed thrice. The concentration was determined by a freeze dryer (Titec VD-800F, Japan). Liquid and powder forms of the sample were used for further characterization and other purposes as given below.

2.5. Transmission Electron Microscopy (TEM) Analysis. AgNPs were sent to Central Laboratory of Pukyong National University, Busan, Republic of Korea, for shape and size analysis by TEM (JEM-2100F, JEOL, Japan). The average size of the nanoparticles was determined by using ImageJ software program.

2.6. Energy Dispersive X-Ray Spectrophotometer (EDX) Anal$y$ sis. The presence of elemental silver in AgNPs was studied by energy dispersive X-ray spectrophotometer (JEM$2100 \mathrm{~F}$, JEOL, Japan) where accelerating voltage of $20 \mathrm{keV}$ was operated. This experiment was also carried out by Central Laboratory of Pukyong National University, Busan, Republic of Korea.
2.7. Fourier Transform Infrared Spectroscopy (FTIR) Analysis. FTIR spectra of lyophilised AgNPs were obtained after mixing with potassium bromide and by using a Perkin Elmer (USA) Spectrum 100. Spectra were measured over the frequency range $4000-225 \mathrm{~cm}^{-1}$, with a resolution of $\mathrm{cm}^{-1}$.

2.8. Bacterial Growth Inhibition Assay. Growth inhibition of five pathogenic bacteria \{Listeria monocytogenes $(+)$, Bacillus subtilis (-), Salmonella typhi (-), Shigella sonnei (-), and Streptococcus aureus $(+)\}$ was studied with different concentrations of silver nanoparticles $(12.5-100 \mu \mathrm{g} / \mathrm{mL})$ in bacterial nutrient broths according to Kabir et al. [11] with a little modification in the method. Small and narrow glass test tubes with cotton were autoclaved and $2 \mathrm{~mL}$ of sterilized nutrient broth media was added to each test tube. Then, $50 \mu \mathrm{L}$ of freshly cultured bacterial strain was added to each tube except to the tube for negative control. After that, $12.5-100 \mu \mathrm{g} / \mathrm{mL}$ of AgNPs was added to test tubes except to the tube for positive control and incubated for $24 \mathrm{~h}$ at $37^{\circ} \mathrm{C}$. Absorbance was measured at $630 \mathrm{~nm}$ at the initial stage and after the incubation period. Finally, percentage of growth inhibition was calculated by using the following formula:

Percentage of inhibition

$$
\begin{aligned}
= & \left\{\frac{(\text { absorbance of control }- \text { absorbance of test })}{\text { absorbance of control }}\right\} \\
& \times 100 .
\end{aligned}
$$

2.9. Antibacterial Study by Disc Diffusion Assay. The antibacterial activities of the AgNPs samples were determined by paper disc diffusion assay with slight modification [12]. Bacillus subtilis, Salmonella typhi, Shigella boydii, and Escherichia coli were used as microorganisms. Paper discs $(5 \mathrm{~mm})$ containing nanoparticle samples $(10-40 \mu \mathrm{g} / \mathrm{mL})$, silver nitrate $(10 \mu \mathrm{g} / \mathrm{mL})$, and control (20 units of streptomycin) were placed on sterilized and solidified nutrient agar plates where bacterial suspension was spread out. Diameter of each inhibitory zone $(\mathrm{mm})$ was measured after the incubation at $37^{\circ} \mathrm{C}$ for $24 \mathrm{~h}$.

2.10. Antibiofilm Assay. Klebsiella pneumoniae was used to study the antibiofilm activity of the synthesized AgNPs according to Hasan et al. [13] with a little modification in the method. Briefly, 21 autoclave narrow and small glass test tubes $(1.2 / 10 \mathrm{~cm})$ with cotton were taken and $2 \mathrm{~mL}$ of sterilized nutrient broth media was added to each tube. Then, $50 \mu \mathrm{L}$ of freshly cultured Klebsiella pneumoniae bacterial strain was added to 18 test tubes and 3 tubes remained as the negative control. After that, five concentrations of AgNPs ranging from 5 to $80 \mu \mathrm{g} / \mathrm{mL}$ were added to 15 test tubes and the remaining three tubes were used as positive control. Finally, all test tubes were incubated at $37^{\circ} \mathrm{C}$ for $96 \mathrm{~h}$. The formation of biofilm in the test tubes was monitored at $24 \mathrm{~h}$ interval.

2.11. EAC Cell Proliferation Assay. To detect EAC cells proliferation, MTT \{3-(4,5-dimethylthiazol-2-yl)-2,5-diphenyltetrazolium bromide\} colorimetric assay was used according 


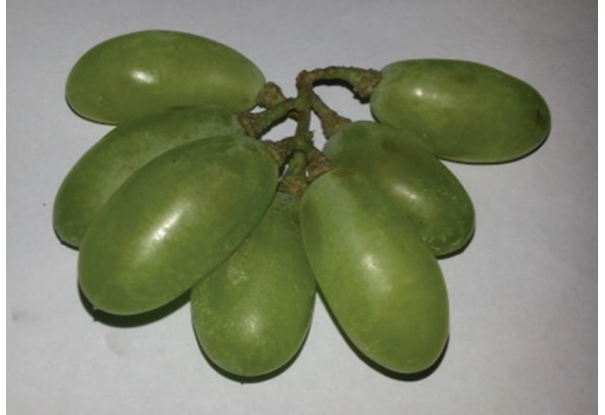

(a)

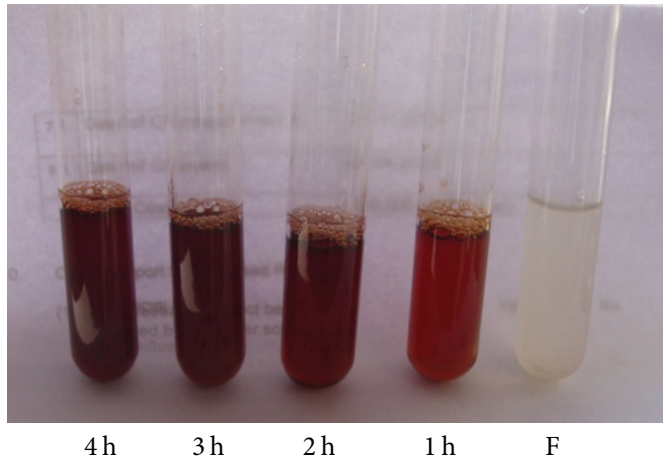

(b)

FIGURE 1: (a) Vitis vinifera fruit, (b) fruit extract, and AgNPs solution at different reaction time (h). F denotes the fruit extract.

to the method of Kabir et al. [14]. Briefly, around $5 \times 10^{5}$ EAC cells in RPMI-1640 media were plated in each well of the 96-well flat-bottom titer plate in the presence and absence of different concentrations of AgNPs $(4-128 \mu \mathrm{g} / \mathrm{mL})$ and incubated at $37^{\circ} \mathrm{C}$ in $\mathrm{CO}_{2}$ incubator for $24 \mathrm{~h}$. After removal of aliquot from each well, $180 \mu \mathrm{L}$ of PBS and $20 \mu \mathrm{L}$ of MTT $(5 \mathrm{mg} / \mathrm{mL})$ were added and incubated at $37^{\circ} \mathrm{C}$ for $4 \mathrm{~h}$. Then, the aliquot was removed again and $100 \mu \mathrm{L}$ acidic isopropanol was added into each well. The plate was agitated for $20 \mathrm{sec}$ and incubated at $37^{\circ} \mathrm{C}$ for $1 \mathrm{~h}$, and, finally, the absorbance was taken at $570 \mathrm{~nm}$ using a titer plate reader.

2.12. Brine Shrimp Nauplii Lethality Assay. Brine shrimp nauplii (Artemia salina L.) lethality assay was studied according to the method of Kabir et al. [11]. Ten brine shrimp nauplii were placed in each vial containing 22.5, 45, 90, 180, 270, and $360 \mu \mathrm{g} / \mathrm{mL}$ of AgNPs containing $3.5 \mathrm{~mL}$ of artificial sea water and kept at $30^{\circ} \mathrm{C}$ for $24 \mathrm{~h}$ under a continuous light regime. After that, the percentage of mortality of the nauplii was calculated by Probit analysis as described by Finney [15].

2.13. Statistical Analysis. The experimental results are expressed as the mean \pm SD (standard deviation). Data have been calculated by one-way ANOVA followed by Dunnett's $t$-test using SPSS software, version 16.

\section{Results}

3.1. AgNPs Synthesis. In this experiment, green V. vinifera extract was used for AgNPs formation. 2.5, 3.0, 3.5, 4.0, and $4.5 \mathrm{mM}$ of silver nitrate solution were added to the $V$. vinifera extract at $1: 1$ ratio $(\mathrm{v} / \mathrm{v})$ and kept in room temperature for $4 \mathrm{~h}$. A sharp plasmon absorption band of nanoparticles was observed using 3.5 to $4.5 \mathrm{mM}$ of $\mathrm{AgNO}_{3}$. Intensity of the brown colored solution was also checked by the incubation of $V$. vinifera extract with $4 \mathrm{mM} \mathrm{AgNO}_{3}$ for $1 \mathrm{~h}$ to $4 \mathrm{~h}$. Intensity of the solution color was increased with the reaction time (Figures 1(a) and 1(b)).
3.2. UV-Visible Spectra for AgNPs Synthesis. UV-visible spectra method is widely used for the structural characterization of nano-based materials. UV-visible spectra for AgNPs ranged from 250 to $700 \mathrm{~nm}$. A surface plasmon absorption band for AgNPs at $449 \mathrm{~nm}$ is shown in Figures 2(a) and 2(b).

3.3. TEM Analysis. Shape of the synthesized silver nanoparticles was characterized by a transmission electron microscope as shown in Figures 3(a) and 3(b). From the figure, it became evident that the particles are spherical and highly monodispersed with an average diameter of $17 \mathrm{~nm}$ as shown in Figure 3(c).

3.4. EDX Analysis. The fruit extract of $V$. vinifera synthesized silver nanoparticles produces a signal at $20 \mathrm{keV}$ which reveals the presence of AgNPs. Presence of the mild signal from silver (6.01\%) atoms in the nanoparticles, weak signals from oxygen $(2.96 \%)$ and chlorine $(0.46 \%)$ atoms, and strong signals from carbon (90.57\%) atoms is confirmed (Figure 3(d)).

3.5. FTIR Analysis. FTIR spectra of $V$. vinifera (grape) extract and AgNPs were presented in Figure 4. FTIR spectrum of grape extract shows different major peaks positioned at $3295.29,2932.39,1634.70,1412.24,1079.53$, and $631.87 \mathrm{~cm}^{-1}$. On the other hand, FTIR spectrum of synthesized AgNPs shows the presence of major peaks at $3429.45,2924.37$, $1648.12,1384.45,1065.21$, and $616.4935 \mathrm{~cm}^{-1}$.

3.6. Antibacterial Study by Growth Inhibition Method. Growth inhibition at different concentrations of $V$. vinifera mediated AgNPs of five pathogenic Gram-positive and Gram-negative bacteria $\{$ Listeria monocytogenes (+), Bacillus subtilis (-), Salmonella typhi (-), Shigella sonnei (-), and Streptococcus aureus $(+)\}$ was observed and shown in Figure 5. Among those, Streptococcus aureus was the most sensitive towards AgNPs as $90 \%$ growth inhibition was observed at $100 \mu \mathrm{g} / \mathrm{mL}$ of AgNPs, while $82.18 \%, 57.00 \%, 53.18 \%$, and 49.03\% growth inhibition was observed for Bacillus subtilis, Listeria monocytogenes, Salmonella sonnei, and Salmonella typhi, respectively. 


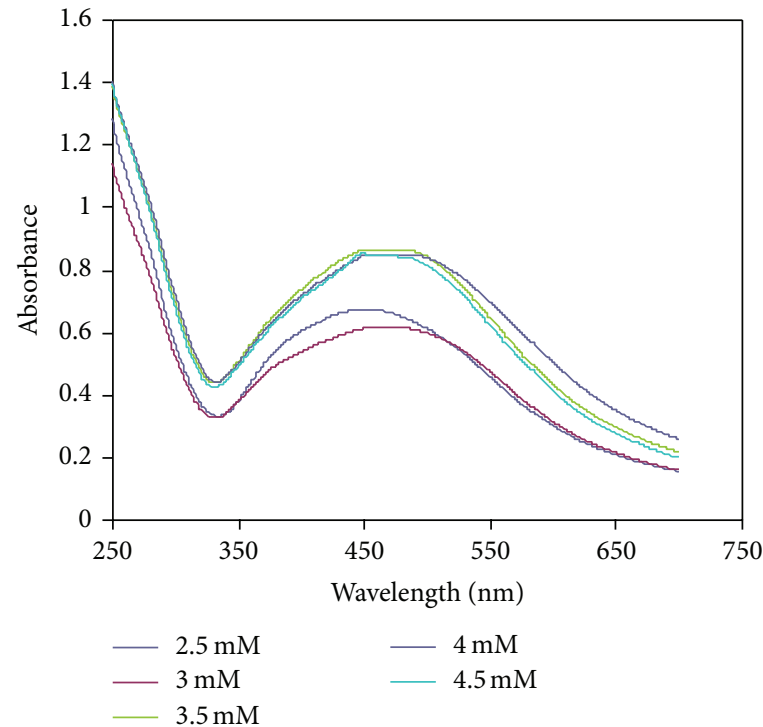

(a)

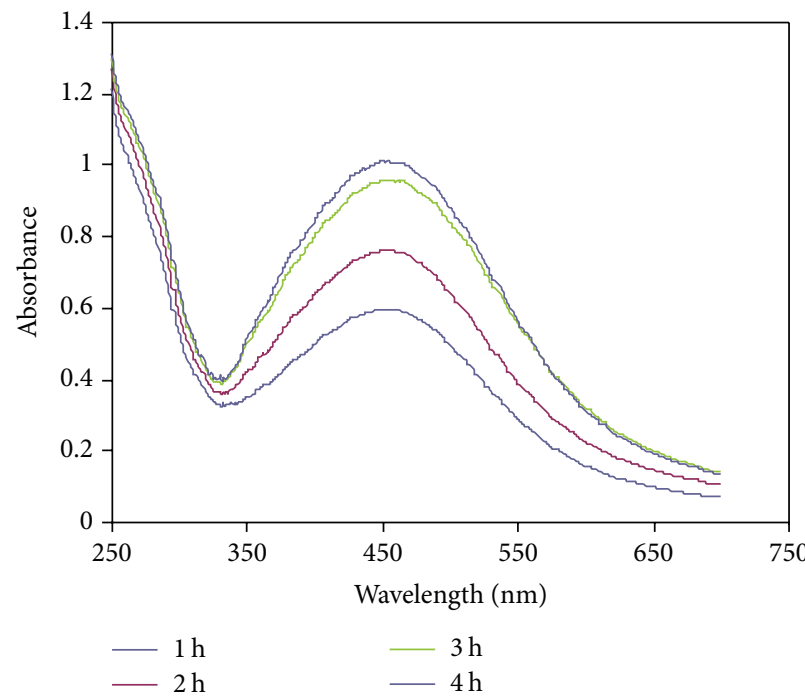

(b)

FIgURE 2: UV-visible absorption spectra of the AgNPs biosynthesis by V. vinifera. (a) Using various moles of concentration of $\mathrm{AgNO}_{3}$; (b) using different time $(\mathrm{h})$ for reaction.

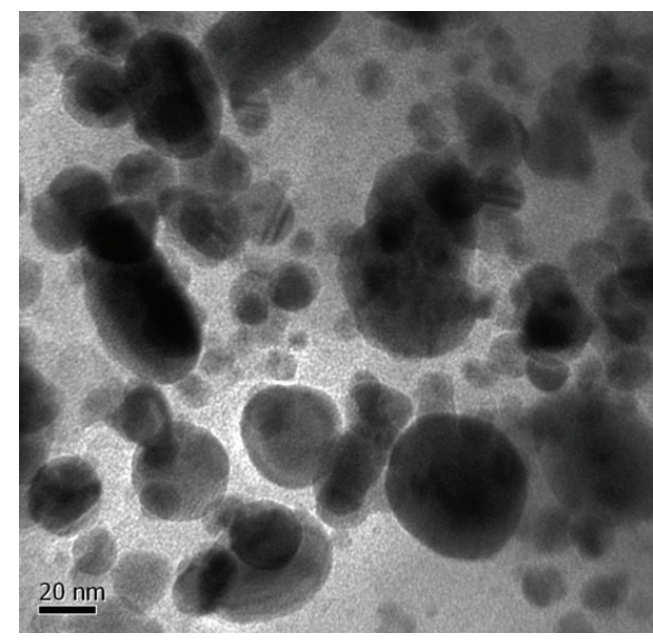

(a)

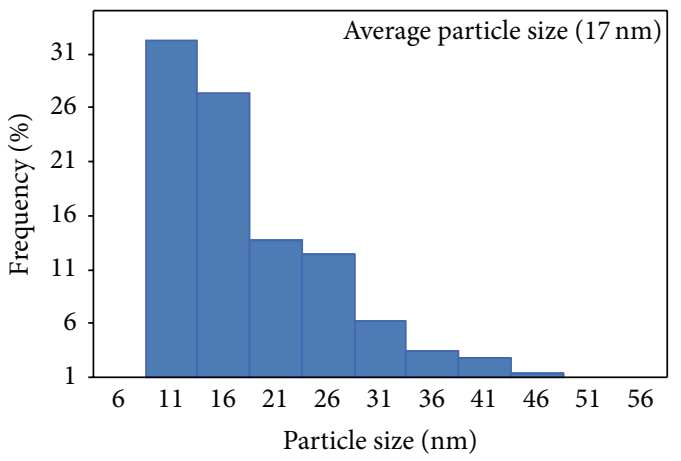

(c)

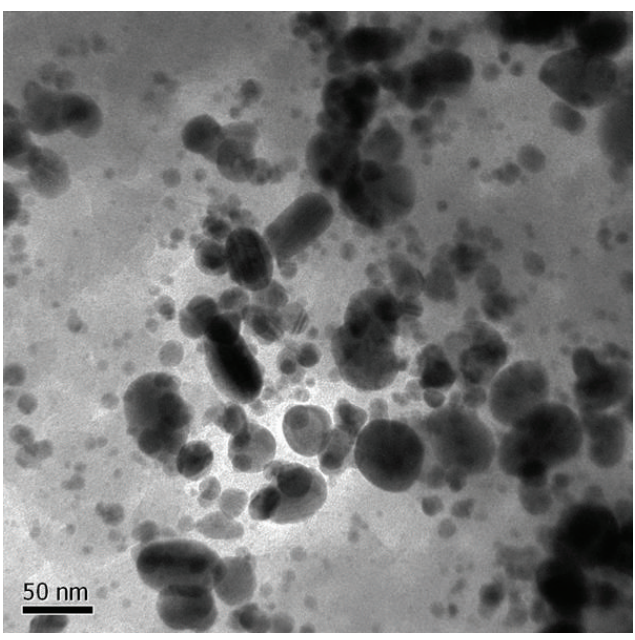

(b)

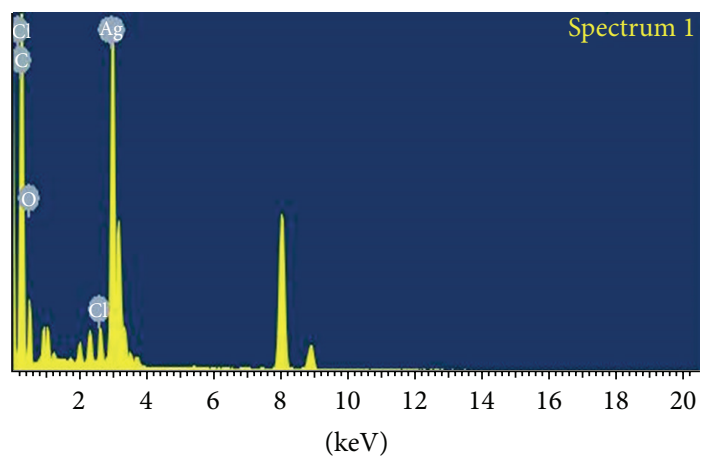

Full scale 11279 cts cursor: 0.000

(d)

Figure 3: TEM images of AgNPs formed by reduction of $\mathrm{AgNO}_{3}$ using V. vinifera. (a) $20 \mathrm{~nm}$; (b) $50 \mathrm{~nm}$, (c) frequency percentage of particle size distribution, and (d) EDX spectra of prepared AgNPs by $V$. vinifera. 


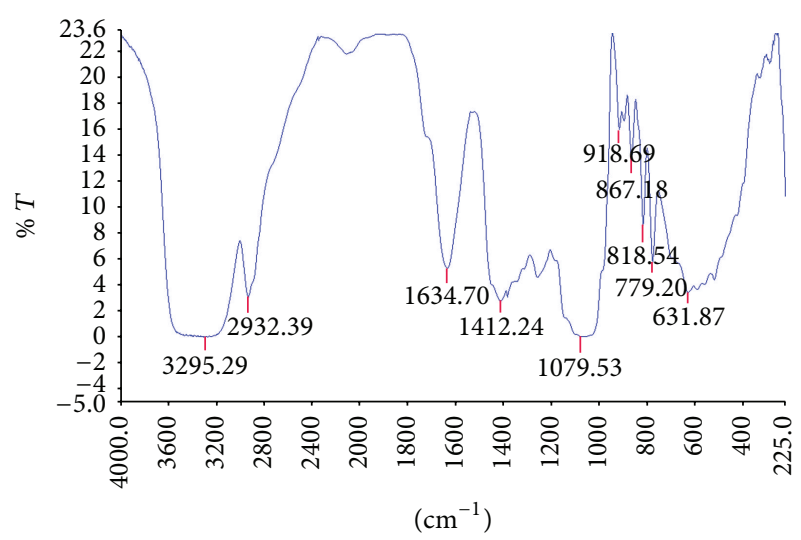

(a)

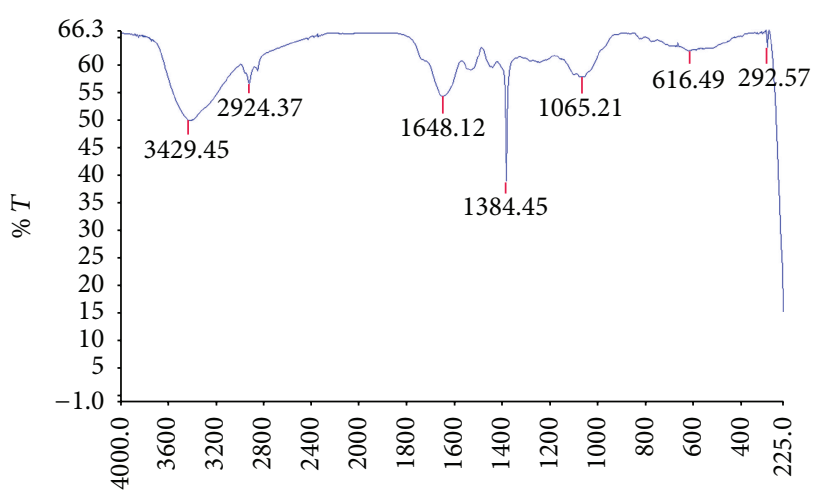

$\left(\mathrm{cm}^{-1}\right)$

(b)

FIgURE 4: FTIR spectrum of $V$. vinifera mediated AgNPs. (a) V. vinifera extract; (b) synthesized AgNPs.

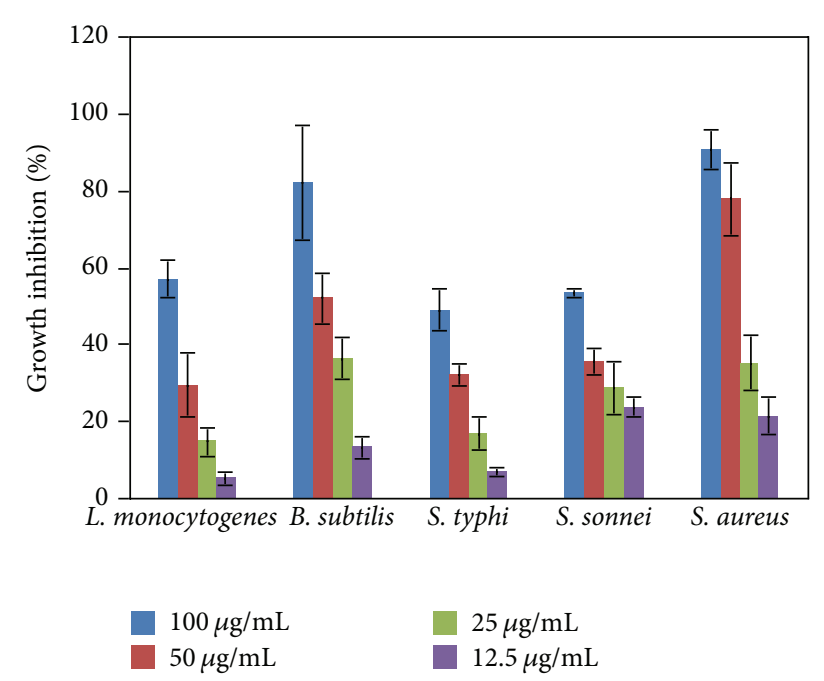

Figure 5: Bacterial growth inhibition percentage of synthesized AgNPs from $V$. vinifera $(n=3$, mean $\pm \mathrm{SD})$.

3.7. Bacterial Zone Inhibition. The bacterial zone of inhibition was observed against Bacillus subtilis, Salmonella typhi, Shigella boydii, and Escherichia coli and zones of inhibition were found to be $14,8,10$, and $7.5 \mathrm{~nm}$ in diameter, respectively, when $40 \mu \mathrm{g} / \mathrm{mL}$ of $V$. vinifera mediated AgNPs was used. The zone of inhibition for these bacteria was $18,12,16$, and $12 \mathrm{~mm}$ when 20 units of streptomycin and 13, 9.5, 12, and $10 \mathrm{~nm}$ when $10 \mu \mathrm{g} / \mathrm{mL}$ silver nitrate was used. These results reveled that $V$. vinifera mediated AgNPs are a toxic compound for these four bacteria and less toxic compared to streptomycin and silver nitrate. Among these four bacteria, Bacillus subtilis was the most sensitive one towards AgNPs as the zone of inhibition was the biggest. The bacterial zone of inhibition is summarized in Table 1.

3.8. Antibiofilm Activity. We analyzed the impact of AgNPs at various concentrations on the formation of biofilm by $K$. pneumoniae. After $24 \mathrm{~h}$ of treatment, biofilm was produced
TABLE 1: Zone of bacterial growth inhibition of synthesis AgNPs by $V$ vinifera.

\begin{tabular}{|c|c|c|c|c|c|}
\hline \multirow{3}{*}{$\begin{array}{l}\text { Sample } \\
\text { name }\end{array}$} & \multirow{3}{*}{$\begin{array}{l}\text { Name of } \\
\text { bacteria }\end{array}$} & \multicolumn{4}{|c|}{$\begin{array}{l}\text { Zone of bacterial growth } \\
\text { inhibition }(\mathrm{mm})\end{array}$} \\
\hline & & \multicolumn{3}{|c|}{$\operatorname{AgNPs}(\mu \mathrm{g} / \mathrm{mL})$} & \multirow{2}{*}{$\begin{array}{c}\text { Streptomycin } \\
\text { (unit) } \\
20\end{array}$} \\
\hline & & 40 & 20 & 10 & \\
\hline \multirow{4}{*}{ Vitis vinifera } & $\begin{array}{c}\text { Bacillus } \\
\text { subtilis }\end{array}$ & 14 & 12 & 11 & 18 \\
\hline & $\begin{array}{c}\text { Salmonella } \\
\text { typhi }\end{array}$ & 8 & 8 & 7.5 & 12 \\
\hline & $\begin{array}{c}\text { Shigella } \\
\text { boydii }\end{array}$ & 10 & 9 & 9 & 16 \\
\hline & $\begin{array}{c}\text { Escherichia } \\
\text { coli }\end{array}$ & 7.5 & 7 & 7 & 12 \\
\hline
\end{tabular}

by $K$. pneumoniae at the doses of 5,10 , and $20 \mu \mathrm{g} / \mathrm{mL}$ and no biofilm was observed at 40 and $80 \mu \mathrm{g} / \mathrm{mL}$ concentration of AgNPs till $96 \mathrm{~h}$. On the other hand, biofilm was observed in the test tube containing no AgNPs.

3.9. Antiproliferative Activity of AgNPs on EAC Cell. In vitro MTT assay was used for the investigation of AgNPs effect on EAC cells growth. AgNPs induced EAC cell death and the effect was found to be present in a dose-dependent manner (Figure 6). A 100\% growth inhibition of EAC cells was noted at the dose of $128 \mu \mathrm{g} / \mathrm{mL}$. However, the growth inhibitory effect of AgNPs was found to get decreased gradually with reduced concentrations, and $12.01 \%$ growth inhibition was observed at $4 \mu \mathrm{g} / \mathrm{mL}$ (the lowest concentration of AgNPs used in this study).

3.10. Toxicity. We used AgNPs at various concentrations for determining its toxicity against brine shrimp nauplii. The highest mortality was observed at a concentration of $360 \mu \mathrm{g} / \mathrm{mL}$ and the mortality rate decreased with reduced AgNPs concentration. $\mathrm{LC}_{50}$ value of the synthesized AgNPs was calculated to be $163 \mu \mathrm{g} / \mathrm{mL}$. The percentage of mortality 


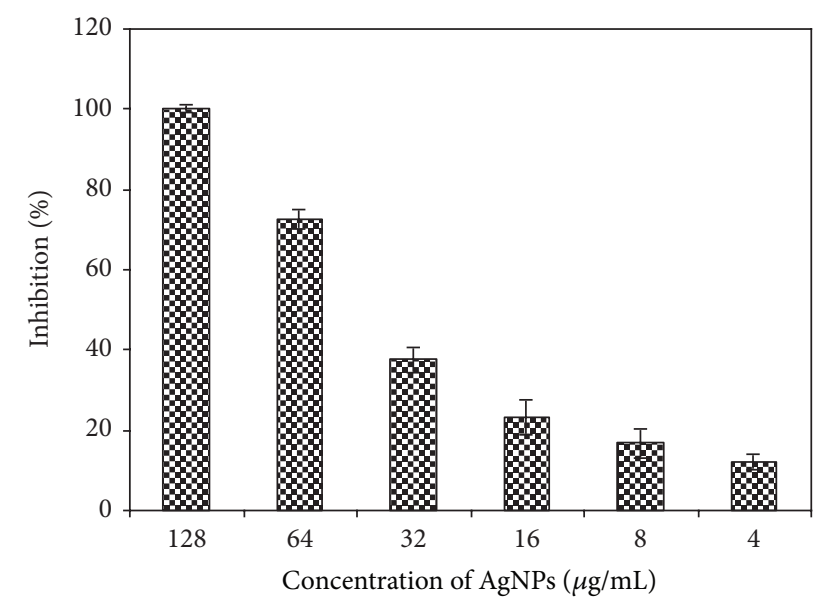

Figure 6: Synthesized AgNPs inhibit EAC cells growth. EAC cells were treated with various doses of AgNPs for $24 \mathrm{~h}$ in RPMI-1640 medium. The growth inhibition was measured by MTT assay $(n=3$, mean $\pm S D$ ).

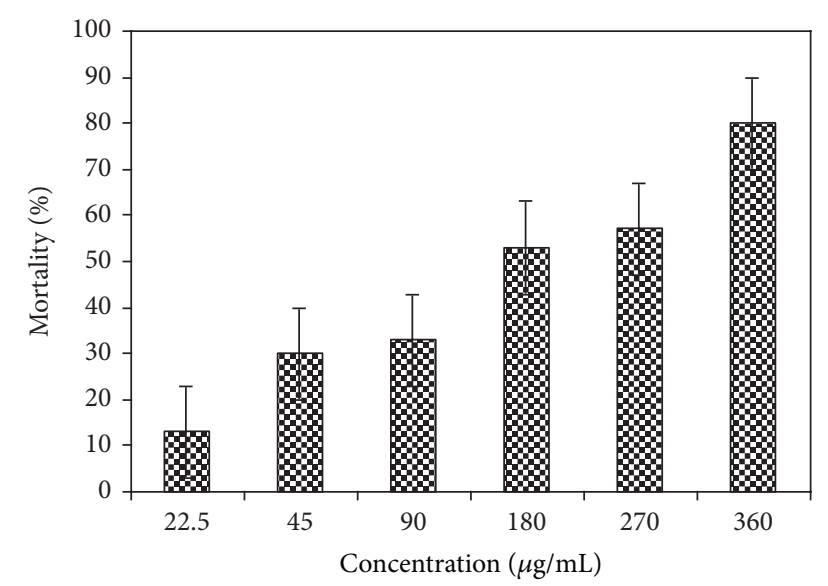

FIGURE 7: Percentage of mortality of brine shrimp nauplii treated with synthesized AgNPs by $V$. vinifera at different concentrations applied for $24 \mathrm{~h}(n=3$, mean $\pm \mathrm{SD})$.

was found to be directly proportional to the concentration of AgNPs as shown in Figure 7.

\section{Discussion}

In the present study, AgNPs were formed at room temperature by treating $\mathrm{AgNO}_{3}$ with green $V$. vinifera extract. The formation of $V$. vinifera extract mediated AgNPs was confirmed by the change of solution color from white to brown by the reduction of $\mathrm{Ag}^{+}$ions to $\mathrm{Ag}^{0}$. It can happen due to the presence of various biomolecules in $V$. vinifera extract. Silver nitrate solution was colorless in appearance when it was mixed with $V$. vinifera extract; but the color changed at suitable conditions which is a primary indication for the formation of AgNPs.

Presence of absorbance peaks between 400 and $450 \mathrm{~nm}$ is another characteristic of the formation of silver nanoparticles. In line with this, green $V$. vinifera mediated AgNPs showed a characteristic absorbance peak at a wavelength of $449 \mathrm{~nm}$ by UV-visible spectroscopy. Behera and Nayak [9] and Gnanajobitha et al. [10] reported that Indian black $V$. vinifera assisted AgNPs showed plasmon absorption band at $410 \mathrm{~nm}$ and around $450 \sim 470 \mathrm{~nm}$. It may have happened due to the species varieties of grapes. With an increase in the reaction time from 1 to $4 \mathrm{~h}$, a colloidal solution of AgNPs showed a very intense color and found a sharp band. This result revealed that the formation of particles became complete after $4 \mathrm{~h}$ incubation time. Similar results have been reported by Chauhan et al. [16] and Gnanajobitha et al. [10].

Shape of the synthesized AgNPs was spherical, as determined by TEM, and highly monodispersed with an average diameter of approximately $17.0 \mathrm{~nm}$. Most of the plant mediated silver nanoparticles were reported to be spherical. Behera and Nayak [9] and Gnanajobitha et al. [10] reported that Indian black $V$. vinifera assisted AgNPs were also spherical and the average diameters were between 30 and $40 \mathrm{~nm}$. The presence of elemental silver along with other elements $\mathrm{C}$, $\mathrm{O}$, and $\mathrm{Cl}$ in $V$. vinifera mediated AgNPs was confirmed by EDX. The other signals except for silver are recorded possibly due to elements $(\mathrm{C}, \mathrm{O}$, and $\mathrm{Cl}$ ) from organic moieties like enzymes or proteins present in the extract of $V$. vinifera [17].

FTIR study was carried out to clearly understand the presence of various functional groups in $V$. vinifera (grape) extract and in synthesized AgNPs which are responsible for the bioreduction of $\mathrm{AgNO}_{3}$ into AgNPs. In case of $V$. vinifera extract, peaks at $3295.29 \mathrm{~cm}^{-1}$ could be present due to O-H group [18] in polyphenols or polysaccharide. A small peak observed at $2932.39 \mathrm{~cm}^{-1}$ is present due to $\mathrm{CH}$-stretching of alkanes [19]. A sharp and intense peak observed at $1634.70 \mathrm{~cm}^{-1}$ may be ascribed to the stretching vibration of the $(\mathrm{NH}) \mathrm{C}=\mathrm{O}$ indicating amide 1 group [19]. The peak at $1412.24 \mathrm{~cm}^{-1}$ corresponds to $\mathrm{C}-\mathrm{N}$ stretching mode of aromatic amine rings and peak at $1079.53 \mathrm{~cm}^{-1}$ shows the $\mathrm{C}-\mathrm{N}$ stretching of aliphatic amines [20]. The intense peak of $631.87 \mathrm{~cm}^{-1}$ shows the $\mathrm{C}-\mathrm{Cl}$ group of alkyl halides [21]. After the bioreduction, there is a shift in the absorption band of $3295.29-3429.45 \mathrm{~cm}^{-1}, 2932.39-$ $2924.37 \mathrm{~cm}^{-1}, 1634.70-1648.12 \mathrm{~cm}^{-1}, 1412.24-1384.45 \mathrm{~cm}^{-1}$, $1079.53-1065.21 \mathrm{~cm}^{-1}$, and $631.87-616.49 \mathrm{~cm}^{-1}$. Shifting of the band from $1634.70-1648.12 \mathrm{~cm}^{-1}$ may have happened due to the binding of $(\mathrm{NH}) \mathrm{C}=\mathrm{O}$ group with the nanoparticles. The $(\mathrm{NH}) \mathrm{C}=\mathrm{O}$ groups within the cage of cyclic peptides are involved in stabilizing the nanoparticles. Thus, the peptides may play an important role in the reduction of $\mathrm{AgNO}_{3}$ into AgNPs. The abovementioned shift was observed during the nanoparticle formation from various sources of extracts [22, 23].

It is now well established that AgNPs exhibit strong antibacterial activity. From the present study, it became evident that the growth inhibition of five pathogenic bacteria followed a dose-dependent manner as the inhibition increased with AgNPs concentration. Presently, synthesized AgNPs can inhibit the growth of both Gram-positive and Gram-negative bacteria.Some researchers reported AgNPs to be more effective towards Gram-negative bacteria than Gram-positive bacteria due to the presence of much thicker 
outer membrane and peptidoglycan layer [24]. Another researcher reported that Mukia maderaspatana leaf extract mediated synthesized AgNPs were most effective against Gram-positive bacteria [25]. The mechanism of action of AgNPs against different bacteria is unknown. It has been reported that AgNPs cause formation of pores/pits in the bacterial cell wall [26] that may depend on the particle size. A small nanoparticle on bacterial surfaces increases the permeability [27], binds the functional groups of DNA and proteins, and destroys the cell [26]. Toxicity of $V$. vinifera extract mediated AgNPs to multidrug resistant pathogenic bacteria (Bacillus subtilis, Salmonella typhi, Shigella boydii, and Escherichia coli) was also confirmed by the disc diffusion method which may have great potentiality in biochemical applications. Comparable observation was found with the Indian variety of black $V$. vinifera [10] assisted AgNPs.

Generally, biofilms are known to provide resistance against several antimicrobial agents [28] and biofilm can be one of the leading causes for a shift from acute-phase diseases to chronic diseases [29]. Most biofilm-forming bacteria associated with human infections are E. faecalis, S. aureus, S. epidermidis, Streptococcus viridans, E. coli, K. pneumoniae, Moraxella catarrhalis, Proteus mirabilis, and $P$. aeruginosa [30]. Nowadays, researchers became interested in controlling the formation of bacterial biofilm using green AgNPs. Therefore, in the present investigation, multidrug resistance bacteria K. pneumoniae were cultured in the presence and absence of AgNPs and it was found that the growth of $K$. pneumonia was completely inhibited in the presence of AgNPs at $40 \mu \mathrm{g} / \mathrm{mL}$. Several studies reported the antibiofilm activity of silver nanoparticles [29, 31]. Franci et al. [29] reported that AgNPs inhibit biofilm formation by altering the membrane of K. pneumoniae and causing irreversible damage on bacterial cells, alteration of membrane permeability, and respiration of $K$. pneumoniae. Palanisamy et al. [31] also reported that AgNPs inhibited biofilm formation of P. aeruginosa. Other researchers stated that Calotropis procera assisted AgNPs have antibiofilm activity against Vibrio cholerae and enterotoxic Escherichia coli [32].

In case of the anticancer study of $V$. vinifera mediated AgNPs, EAC cell was selected. A 100\% of EAC cell growth inhibition in vitro was observed at $128 \mu \mathrm{g} / \mathrm{mL}$ of AgNPs concentration. However, it was reported that varieties of marine algae assisted AgNPs showed 74 99\% EAC cell growth inhibition in vitro at $98 \mu \mathrm{g} / \mathrm{mL}$ of AgNPs concentration [33]. Several in vitro studies demonstrated the anticancer effect of plant mediated AgNPs against different cancer cell lines $[6,34]$. For example, Vasanth and coworkers noted $94 \%$ and $80 \%$ growth inhibition of Hela cells with treatments of AgNPs at doses of 250 and $100 \mu \mathrm{g} / \mathrm{mL}$, respectively [6]. Similar result was also revealed by Kaler et al. [34] against MCF-7 cells. The green synthesized AgNPs have selective cytotoxicity on cancer cells and are more toxic for cancer cells than for noncancerous normal cells. For instance, the anticancer activity of Potentilla fulgens mediated AgNPs was tested against normal and cancer cell lines [35]. A $42 \%$ and $40 \%$ of growth inhibition were reported for MCF-7 and U87 cancer cell lines, respectively, at $6 \mu \mathrm{g} / \mathrm{mL}$ concentration, while, at the same concentration, $17.8 \%$ and $19.7 \%$ growth inhibition were reported for lymphocytes (PHA-) and lymphocytes (PHA+), respectively [35]. Thuja occidentalis leaves mediated AgNPs also exhibited similar types of activities [36]. Therefore, from the above results, we can assume that synthesized AgNPs might have negligible cytotoxic effect on normal cells with notable anticancer properties. Further studies will elucidate the exact cause of cancer cell growth inhibition by AgNPs.

For the determination of toxicity, brine shrimp nauplii cytotoxicity assay is an as old but effective method as brine shrimps are regarded as one of the standard organisms for checking cytotoxicity. In the present study, $\mathrm{LC}_{50}$ value of the synthesized AgNPs was calculated to be $163 \mu \mathrm{g} / \mathrm{mL}$. In accordance with the present study, Vijayan et al. [37] reported $50 \%$ mortality of brine shrimp nauplii at $88.91 \mu \mathrm{g} / \mathrm{mL}$ concentration of AgNPs synthesized from seaweed Turbinaria conoides, which was a more toxic compound compared to our synthesized AgNPs. Therefore, the biosynthesized V. vinifera mediated AgNPs can definitely be used as an ecofriendly antibacterial and anticancer agent in food and pharmaceutical industries.

\section{Conclusions}

In the present study, Bangladeshi V. vinifera is a good source for the synthesis of AgNPs having $17 \mathrm{~nm}$ of average size with a spherical shape. The reduction of $\mathrm{Ag}^{+}$and the stabilization of AgNPs occurred through the participation of fruit proteins and metabolites. V. vinifera (green) assisted AgNPs exhibited potent antibacterial and anticancer activity in vitro against EAC cells, although the toxicity against brine shrimp nauplii was moderate. Therefore, we can say that $V$. vinifera (green) assisted AgNPs can be a potential antibacterial and antiproliferative agent in the biomedical sector.

\section{Disclosure}

The authors alone are responsible for the content and writing of the paper.

\section{Competing Interests}

The authors declare that there are no competing interests in this paper.

\section{Acknowledgments}

This research work was funded by the Ministry of Science and Technology (Grant no: 39.009.002.01.00.057.20152016/922/Phys-362), Bangladesh.

\section{References}

[1] C. K. Simi and T. E. Abraham, "Hydrophobic grafted and crosslinked starch nanoparticles for drug delivery," Bioprocess and Biosystems Engineering, vol. 30, no. 3, pp. 173-180, 2007.

[2] M. Singh, S. Singh, S. Prasada, and I. S. Gambhir, "Nanotechnology in medicine and antibacterial effect of silver nanoparticles," Digest Journal of Nanomaterials and Biostructures, vol. 3, pp. 115-122, 2008. 
[3] P. Mohanpuria, N. K. Rana, and S. K. Yadav, "Biosynthesis of nanoparticles: technological concepts and future applications," Journal of Nanoparticle Research, vol. 10, no. 3, pp. 507-517, 2008.

[4] Y. Zhang, H. Peng, W. Huang, Y. Zhou, and D. Yan, "Facile preparation and characterization of highly antimicrobial colloid Ag or Au nanoparticles," Journal of Colloid and Interface Science, vol. 325, no. 2, pp. 371-376, 2008.

[5] S. Kokura, O. Handa, T. Takagi, T. Ishikawa, Y. Naito, and T. Yoshikawa, "Silver nanoparticles as a safe preservative for use in cosmetics," Nanomedicine: Nanotechnology, Biology, and Medicine, vol. 6, no. 4, pp. 570-574, 2010.

[6] K. Vasanth, K. Ilango, R. Mohankumar, A. Agrawal, and G. P. Dubey, "Anticancer activity of Moringa oleifera mediated silver nanoparticles on human cervical carcinoma cells by apoptosis induction," Colloids and Surfaces B: Biointerfaces, vol. 117, pp. 354-359, 2014.

[7] A. Naila, D. Nadia, and Q. S. Zahoor, "Stable silver nanoparticles synthesis by Citrus sinensis (orange) and assessing activity against food poisoning microbes," Biomedical and Environmental Sciences, vol. 27, pp. 815-818, 2014.

[8] H. I. Eman, M. H. K. Mostafa, A. A. S. Fozia, and E. M. Fatma, "Biosynthesis of gold nanoparticles using extract of grape (Vitis vinifera) leaves and seeds," Progress in Nanotechnology and Nanomaterials, vol. 3, pp. 1-12, 2014.

[9] S. Behera and P. L. Nayak, "Green synthesis and characterization of zero valent silver nanoparticles from the extract of Vitis vinifera," World Journal of Nano Science \& Technology, vol. 2, pp. 58-61, 2013.

[10] G. Gnanajobitha, K. Paulkumar, M. Vanaja et al., "Fruitmediated synthesis of silver nanoparticles using Vitis vinifera and evaluation of their antimicrobial efficacy," Journal of Nanostructure in Chemistry, vol. 3, pp. 1-6, 2013.

[11] S. R. Kabir, M. A. Hossen, M. A. Zubair et al., "A new lectin from the tuberous rhizome of kaempferia rotunda: isolation, characterization, antibacterial and antiproliferative activities," Protein \& Peptide Letters, vol. 18, no. 11, pp. 1140-1149, 2011.

[12] W. W. Hun, G. S. Hock, and P. S. Moi, "Antibacterial properties of Malaysian seaweeds," in Algae Biotechnology in the AsiaPacific-Region, pp. 75-81, University of Malaya, Kulalumpur, Malaysia, 1994.

[13] I. Hasan, Y. Ozeki, and S. R. Kabir, "Purification of a novel chitin-binding lectin with antimicrobial and antibiofilm activities from a Bangladeshi cultivar of potato (Solanum tuberosum)," Indian Journal of Biochemistry and Biophysics, vol. 51, no. 2, pp. 142-148, 2014.

[14] S. R. Kabir, M. M. Nabi, M. Nurujjaman et al., " Momordica charantia seed lectin: toxicity, bacterial agglutination and antitumor properties," Applied Biochemistry and Biotechnology, vol. 175, no. 5, pp. 2616-2628, 2015.

[15] D. J. Finney, Probit Analysis, Cambridge University Press, London, UK, 3rd edition, 1971.

[16] S. Chauhan, M. K. Upadhay, N. Rishi, and S. Rishi, "Fungal based synthesis of silver nanoparticles using pomegranate fruit seeds," International Journal of Nanomaterials and Biostructures, vol. 1, pp. 17-21, 2011.

[17] H. Xu and M. Käll, "Modeling the optical response of nanoparticle-based surface Plasmon resonance sensors," Sensors and Actuators, B: Chemical, vol. 87, no. 2, pp. 244-249, 2002.

[18] J. Y. Song, H.-K. Jang, and B. S. Kim, "Biological synthesis of gold nanoparticles using Magnolia kobus and Diopyros kaki leaf extracts," Process Biochemistry, vol. 44, no. 10, pp. 1133-1138, 2009.
[19] S. Marimuthu, A. A. Rahuman, G. Rajakumar et al., "Evaluation of green synthesized silver nanoparticles against parasites," Parasitology Research, vol. 108, no. 6, pp. 1541-1549, 2011.

[20] D. Baishya, N. Sharma, and R. Bora, "Green synthesis of silver nanoparticle using Bryophyllum pinnatum (Lam.) and monitoring their antibacterial activities," Archives of Applied Science Research, vol. 4, pp. 2098-2104, 2012.

[21] S. Rajeshkumar, C. Kannan, and G. Annadurai, "Green synthesis of silver nanoparticles using marine brown Algae turbinaria conoides and its antibacterial activity," International Journal of Pharma and Bio Sciences, vol. 3, no. 4, pp. 502-510, 2012.

[22] R. R. R. Kannan, W. A. Stirk, and J. van Staden, "Synthesis of silver nanoparticles using the seaweed Codium capitatum P.C. Silva (Chlorophyceae)," South African Journal of Botany, vol. 86, pp. 1-4, 2013.

[23] N. Shanmugam, P. Rajkamal, S. Cholan et al., "Biosynthesis of silver nanoparticles from the marine seaweed Sargassum wightii and their antibacterial activity against some human pathogens," Applied Nanoscience, vol. 4, no. 7, pp. 881-888, 2014.

[24] G. Singh, P. K. Babele, S. K. Shahi, R. P. Sinha, M. B. Tyagi, and A. Kumar, "Green synthesis of silver nanoparticles using cell extracts of Anabaena doliolum and screening of its antibacterial and antitumor activity," Journal of Microbiology and Biotechnology, vol. 24, no. 10, pp. 1354-1367, 2014.

[25] M. Harshiny, M. Matheswaran, G. Arthanareeswaran, S. Kumaran, and S. Rajasree, "Enhancement of antibacterial properties of silver nanoparticles-ceftriaxone conjugate through Mukia maderaspatana leaf extract mediated synthesis," Ecotoxicology and Environmental Safety, vol. 121, pp. 135-141, 2015.

[26] V. K. Sharma, R. A. Yngard, and Y. Lin, "Silver nanoparticles: green synthesis and their antimicrobial activities," Advances in Colloid and Interface Science, vol. 30, no. 1-2, pp. 83-96, 2009.

[27] T. Hamouda and J. R. Baker, "Antimicrobial mechanism of action of surfactant lipid preparations in enteric gram-negative bacilli," Journal of Applied Microbiology, vol. 89, no. 3, pp. 397403, 2000.

[28] K. Lewis, "Multidrug tolerance of biofilms and persister cells," Current Topics in Microbiology and Immunology, vol. 322, pp. 107-131, 2008.

[29] G. Franci, A. Falanga, S. Galdiero et al., "Silver nanoparticles as potential antibacterial agents," Molecules, vol. 20, no. 5, pp. 8856-8874, 2015.

[30] R. M. Donlan and J. W. Costerton, "Biofilms: survival mechanisms of clinically relevant microorganisms," Clinical Microbiology Reviews, vol. 15, no. 2, pp. 167-193, 2002.

[31] N. K. Palanisamy, N. Ferina, A. N. Amirulhusni et al., "Antibiofilm properties of chemically synthesized silver nanoparticles found against Pseudomonas aeruginosa," Journal of Nanobiotechnology, vol. 12, article 2, 2014.

[32] W. Salem, D. R. Leitner, F. G. Zingl et al., "Antibacterial activity of silver and zinc nanoparticles against Vibrio cholerae and enterotoxic Escherichia coli," International Journal of Medical Microbiology, vol. 305, no. 1, pp. 85-95, 2015.

[33] K. S. Khalifa, R. A. Hamouda, D. Hanafy, and A. Hamza, "In vitro antitumor activity of silver nanoparticles biosynthesized by marine algae," Digest Journal of Nanomaterials and Biostructures, vol. 11, no. 1, pp. 213-221, 2016.

[34] A. Kaler, S. Jain, and U. C. Banerjee, "Green and rapid synthesis of anticancerous silver nanoparticles by Saccharomyces boulardii and insight into mechanism of nanoparticle synthesis," BioMed Research International, vol. 2013, Article ID 872940, 8 pages, 2013. 
[35] A. K. Mittal, D. Tripathy, A. Choudhary et al., "Bio-synthesis of silver nanoparticles using Potentilla fulgens Wall. ex Hook. and its therapeutic evaluation as anticancer and antimicrobial agent," Materials Science and Engineering C, vol. 53, pp. 120-127, 2015.

[36] S. Barua, R. Konwarh, S. S. Bhattacharya et al., "Non-hazardous anticancerous and antibacterial colloidal 'green' silver nanoparticles," Colloids and Surfaces B: Biointerfaces, vol. 105, pp. 37-42, 2013.

[37] S. R. Vijayan, P. Santhiyagu, M. Singamuthu, N. Kumari Ahila, R. Jayaraman, and K. Ethiraj, "Synthesis and characterization of silver and gold nanoparticles using aqueous extract of seaweed, turbinaria conoides, and their antimicrofouling activity," The Scientific World Journal, vol. 2014, Article ID 938272, 10 pages, 2014. 

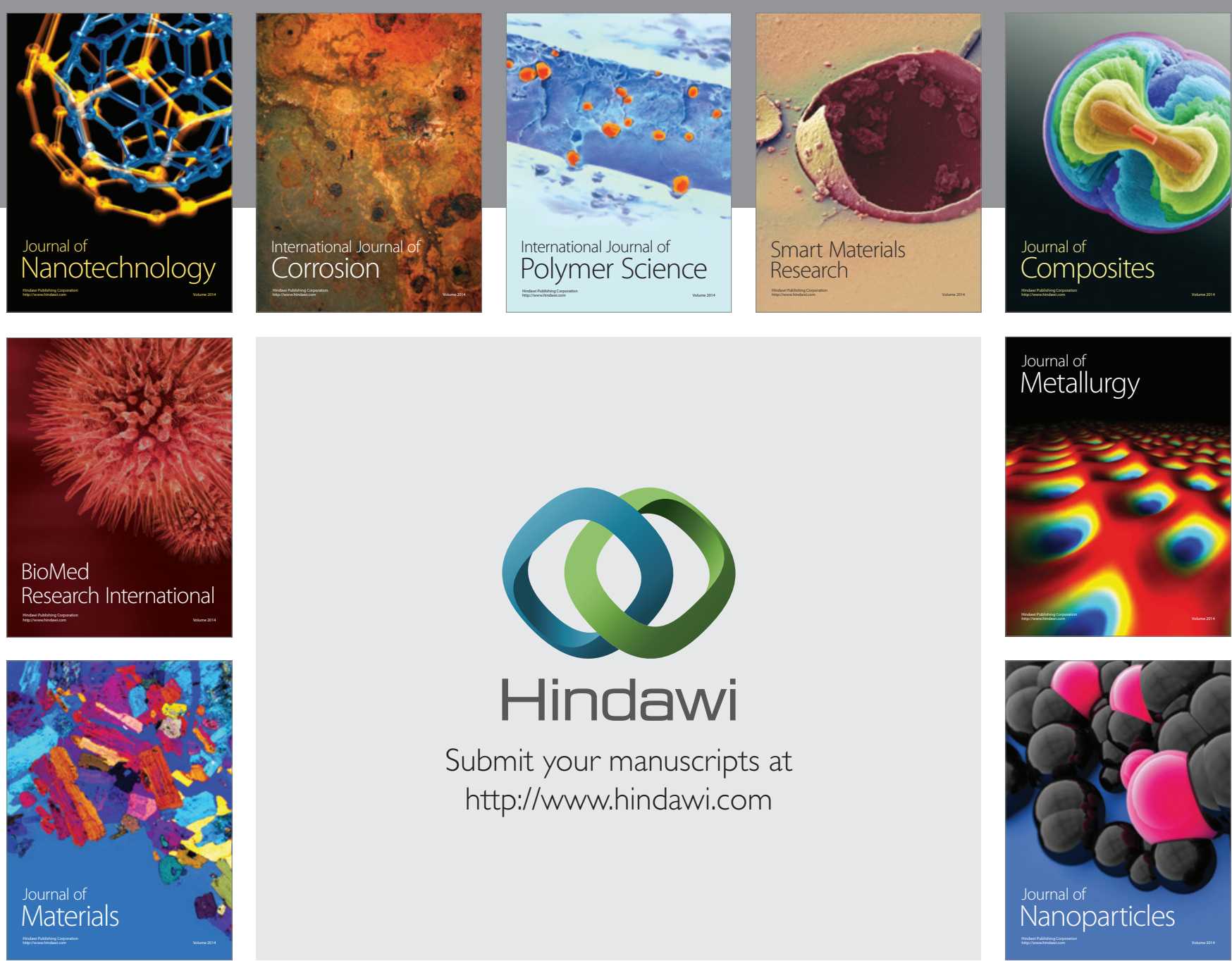

\section{Hindawi}

Submit your manuscripts at

http://www.hindawi.com

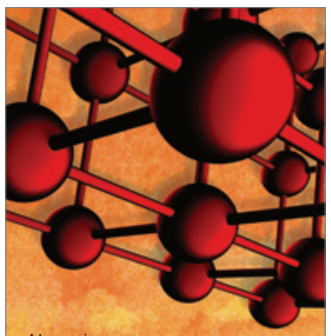

Materials Science and Engineering
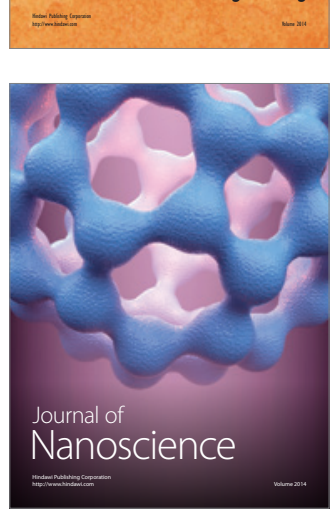
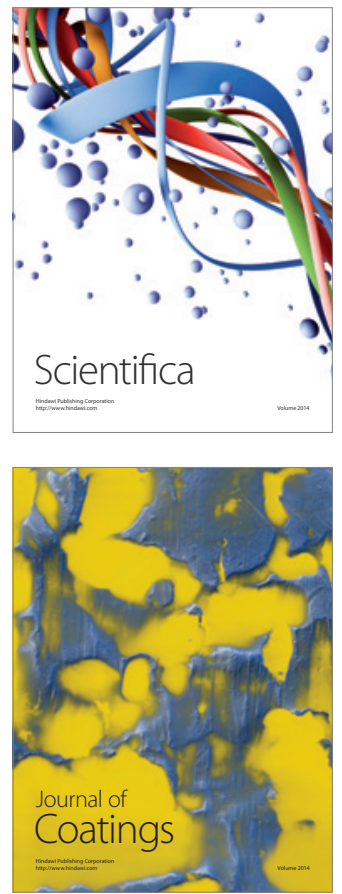
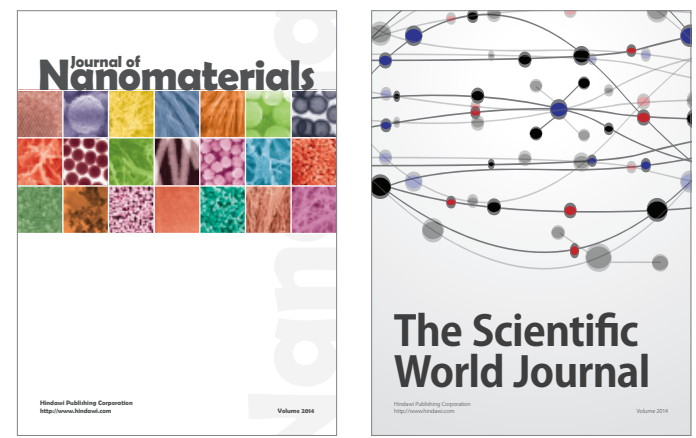

The Scientific World Journal
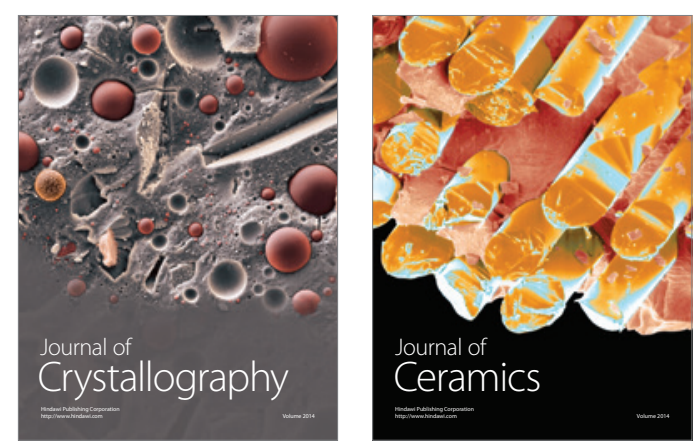
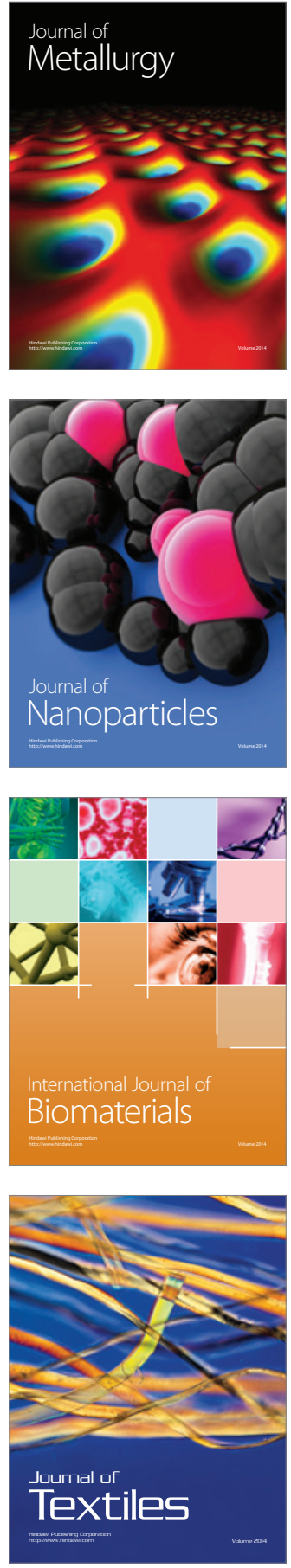